\title{
ARTICLES
}

\section{BREEDERS' AND FARMERS' EXCEPTIONS: HOW VALUABLE ARE THEY FOR THE WORLD AND ARE THEY A NECESSITY FOR THE BRICS COUNTRIES?}

\author{
OLGA GAVRILOVA, \\ National Research University Higher School of Economics \\ (Moscow, Russia)
}

https://doi.org/10.21684/2412-2343-2020-7-3-4-28

These days, the world and every country in it are faced with the task of ensuring food security for people. It's of current interest also for the BRICS countries. The ability to access genetic information and materials for seed production depends on intellectual property regimes. A lack of access to them is a main barrier for contribution in the development of plant varieties. This situation leads to dependence on obtaining hybrid varieties from foreign companies, which poses a threat to food security. It seems that to ensure freedom of research priorities there is a need to provide an opportunity to commercialize new breeding achievements resulting from such discoveries. Correct policymaking also includes the issue of regulating the situation when a patent and a certificate of ownership of the new plant variety are issued to different persons or companies. Capturing in legislation the breeders' exception is necessary for the use of the patented invention in the frame of creating, discovering and developing a new plant variety. The biodiversity of seeds is a high stakes matter especially for the developing countries, where there are many challenges for smallholder farmers. The guarantee of the farmers' right to use the saved seeds on their own farms and to exchange such seeds between themselves may be one of the aspects of food security as it is a base of the traditional agriculture economy in some countries, where smallholder farmers play a significant agricultural role. Also the position and scope of farmers' rights and privileges, based on legislation and, especially, on judicial cases, shows a side of independence on international corporations in the agricultural sector.

Keywords: innovative development; food security; intellectual property; patent law; agriculture; developing countries. 
Recommended citation: Olga Gavrilova, Breeders' and Farmers' Exceptions: How Valuable Are They for the World and Are They a Necessity for the BRICS Countries?, 7(3) BRICS Law Journal 4-28 (2020).

\section{Table of Contents}

\section{Introduction}

\section{Flexibility of International Treaties and Countries' Best Practices} Aimed at Public Interest

2. Regulation of the Breeders' Exception in the BRICS Countries: Key Features and Challenges

2.1. Economic Policy in the BRICS Countries in the Agricultural Sector

2.2. The Breeders' Exception in the Legislation of the BRICS Countries

\section{The Core Question About the Breeders' Exception}

\section{Conclusion}

\section{Introduction}

As a result of technological and institutional changes the world has a chance to ensure food security in every country. It's largely a question of the balance between public and private interests. It's about limiting the impact of big iconic companies who mostly control the agricultural sector: the quantity, quality and prices of food.

There is a growing importance of research and development toward commercially viable plant varieties, while traditional seed supply systems, that are a source of economic independence and resilience in the face of threats such as diseases or climate change, are gradually collapsing. ${ }^{1}$ Much public attention has focused on the expansion of patenting into areas where it was previously unimportant or nonexistent, such as biotechnology and business methods. ${ }^{2}$ But some forms of intellectual property rights can create barriers to the free flow of information and materials (e.g. through farmers' exchange of seeds), which is essential to sustainable food production as well as the development of new varieties. ${ }^{3}$ The increasing influence of patent law hinders innovation in plant breeding in general and limits

Carlos M. Correa, TRIPS-Related Patent Flexibilities and Food Security: Options for Developing Countries Policy Guide, QUNO - ICTSD (September 2012) (Feb. 28, 2020), available at https://quno.org/sites/ default/files/resources/ENGLISH_TRIPS-Related\%20Patent\%20Flexibilities\%20and\%20Food\%20 Security_CORREA.pdf.

2 Adam B. Jaffe \& Josh Lerner, Innovation and its Discontents, 1(3) Capitalism and Society 27 (2006) (Feb. 28, 2020), also available at https://ssrn.com/abstract=2205904.

3 Correa, supra note 1. 
biodiversity, and this leads to a situation where breeding companies with the largest patent portfolios determine which varieties enter the market, thereby paving the way for dominant market positions. ${ }^{4}$ Advances in biotechnology have made it possible to genetically modify plants. Demands increase in terms of obtaining patent protection on the genetic constructs and other tools used in the transformation of plants, as well as on the plants themselves. ${ }^{5}$ But the above-mentioned challenges are so significant, that the need for reasonable patent rights exceptions for the public interest - food security and maximizing the potential for innovation - is acute.

We are talking about the exceptions to patent protection that are applicable during the term of a patent and which provide third parties with the possibility of legal use in a limited scope of the invention patented by the copyright holder. In this article, the exceptions and limitations related to the use of patent-protected objects by agricultural producers and breeders (farmers' and breeders' exceptions) will be considered. Regarding the farmers' rights we are interested in the exemption that allows farmers to save and reuse seeds, and the breeding exemption.

These days the BRICS countries have achieved different results of technological development in the agricultural sector. However each of these states faces challenges in ensuring food security and further innovative development. These challenges will be considered in terms of relevance of improving intellectual property regulation.

Based on the research it was concluded that there is a need of actual policymaking in the BRICS countries within their needs. For clear understanding this article will discuss the flexible provisions of international agreements that allow farmers' and breeders' exemptions to be established. Also types of exceptions and experience will be considered in different countries of the world, including the BRICS countries. Special attention will be paid to a review of legislation and problems in the field of agriculture in Russia and a conclusion will be drawn that the breeders' exception should be established in relation to patent rights, but not for new plant varieties, taking into account the ever-growing inventions in the selection industry.

\section{Flexibility of International Treaties and Countries' Best Practices Aimed at Public Interest}

The protection of plant varieties is a mandatory obligation for Members of the World Trade Organization who are obliged to implement the provisions of the Agreement on Trade-Related Aspects of Intellectual Property Rights (the TRIPS

\footnotetext{
C.G. Trojan, Problem-Solving Approaches to the Issue of the Overlap Between Patent Law and Breeders' Rights in the Plant Breeding Sector, Report (July 2012) (Feb. 28, 2020), available at http://aiph.org/ wp-content/uploads/2015/04/27428-236_engl_report_trojan.pdf.

5 Carlos M. Correa, Patent Protection for Plants: Legal Options for Developing Countries, South Centre, Research Paper 55 (October 2014) (Feb. 28, 2020), available at https://www.southcentre.int/wp-content/ uploads/2014/11/RP55_Patent-Protection-for-Plants_EN.pdf.
} 
Agreement). ${ }^{6}$ According to Article 27.3(b) of the TRIPS Agreement, Members shall provide for the protection of plant varieties either by patents or by an effective sui generis system or by any combination thereof. However, the TRIPS Agreement allows Members to establish exceptions to patent rights under Article 31, with respect to certain provisions. Among them we could define that any use shall be authorized predominantly for the supply of the domestic market of the Member authorizing such use.

Any exception and limitation to patent rights needs to strike the right balance between the freedom to innovate (breed) and the incentive to innovate and should follow the guideline provided in Article 30 TRIPS, i.e. they should (i) not unreasonably conflict with a normal exploitation of the patent and (ii) not unreasonably prejudice the legitimate interests of the patent owner, and (iii) take account of the legitimate interests of third parties. ${ }^{8}$ This provision is compatible with farmers' and/or breeders' use of patented inventions.

Thus, the ability to set exceptions to patent rights is one of the flexible possibilities provided by the TRIPS Agreement. This opportunity is an essential element of patent law, as it aims to take into account the public interest, including ensuring food security and maximizing innovation potential.

The International Convention for the Protection of New Varieties of Plants (the UPOV Convention) directly provides exceptions to the breeder's right. Thus, according to Article 15.1 (iii) the breeder's right shall not extend to acts done for the purpose of breeding other varieties. Article 15 of the UPOV Convention also has a flexible provision that

each Contracting Party may, within reasonable limits and subject to the safeguarding of the legitimate interests of the breeder, restrict the breeder's right in relation to any variety in order to permit farmers to use for propagating purposes, on their own holdings, the product of the harvest which they have obtained by planting, on their own holdings, the protected variety. ${ }^{9}$

The farmer's privilege is an optional exception for UPOV members. This means that the states can choose whether to implement it into their national patent law.

6 Michael Blakeney, Patents and Plant Breeding: Implications for Food Security, 3(3) Amsterdam Law Forum 73 (2011) (Feb. 28, 2020), also available at https://www.researchgate.net/publication/ 228186484_Patents_and_Plant_Breeding_Implications_for_Food_Security.

7 Agreement on Trade-Related Aspects of Intellectual Property Rights (TRIPS) (1994) (Feb. 28, 2020), available at https://www.wto.org/english/docs_e/legal_e/27-trips_01_e.htm.

8 ISF View on Intellectual Property: Brazil (2012) (Feb. 28, 2020), available at https://www.worldseed. org/wp-content/uploads/2015/10/View_on_Intellectual_Property_2012.pdf.

9 International Convention for the Protection of New Varieties of Plants (1961) (Feb. 28, 2020), available at https://www.upov.int//upovlex/en/conventions/1991/content.html. 
The provision usually regards certain crops for which there has been a common practice of farmers saving their own seeds, i.e. seeds are produced on a farm for the purpose of re-sowing on the same farm and not for sale purposes. The provision allows each member of the Union to take into account this practice when providing variety protection..$^{10}$ Finally, the UPOV Convention in Article 17.1 provides that

no contracting party may restrict the free exercise of a breeder's right for reasons other than of public interest.

This is in effect a compulsory licensing obligation."

The absence in the international regulation acts of a single list of grounds for limiting the effect of patent protection explains the variety of approaches for their determination at the national regulation level.

In 2014 WIPO Standing Committee on the Law of Patents made an analysis about exceptions and/or limitations related to farmers' and/or breeders' use of patented inventions existing in the laws of member-states. These exceptions were set in the following countries: Albania, Austria, Bosnia and Herzegovina, Brazil, Bulgaria, Croatia, the Czech Republic, Denmark, Finland, France, Germany, Greece, Latvia, Lithuania, Mexico, the Netherlands, Norway, Poland, Portugal, the Republic of Moldova, Saudi Arabia, Serbia, Slovakia, Spain, Sweden, Switzerland, the United Kingdom, and Vietnam. ${ }^{12}$

The responses from different countries revealed that, in general, there are four types of exceptions and limitations in this area:

- where plant propagating material is commercialized by the patent holder or with his/her consent to a farmer for agricultural use, the farmer is authorized to use the product of his/her harvest for further propagation/multiplication on his/her own farm;

- the effects of a patent do not extend to propagated/multiplied biological material obtained from the biological material placed on the market by the patent holder or with his/her consent, if the propagation/multiplication necessarily results from the application for which the biological material was marketed, provided that the material obtained is not subsequently used for other propagation/multiplication;

- the patent right does not extend to acts for creating or developing a new plant variety;

10 European IPR Helpdesk, Fact Sheet: Plant Variety Protection (December 2018) (Feb. 28, 2020), available at https://www.iprhelpdesk.eu/sites/default/files/newsdocuments/Fact-Sheet-Plant-varietyprotection_0.pdf.

11 Blakeney, supra note 6.

12 WIPO, Standing Committee on the Law of Patents, Exceptions and Limitations to Patent Rights: Farmers' and/or Breeders'Use of Patented Inventions, Twenty-First Session, Geneva, Nov. 3 to 7, 2014 (Feb. 28, 2020), available at https://www.wipo.int/edocs/mdocs/scp/en/scp_21/scp_21_6.pdf. 
- where a breeder cannot exploit a plant variety right without infringing a prior patent, a compulsory license may be issued. ${ }^{13}$

A closer look at some core exceptions related to breeders' and/or farmers' use of patented inventions will help to understand their significance for the public interest.

The associations of plant breeders in France, Germany, the Netherlands, and Switzerland provided an impact for the introduction of the exception in their respective parliaments. The reason for lobbying was based on the necessity to access breeding material, maintain and develop open innovations in breeding lines. ${ }^{14}$

As stated by Sec. 11, no. 2a of the Germany Patent Act the effects of a patent shall not extend to the use of biological material for breeding, discovery and development of a new plant variety type. ${ }^{15}$ Such is how the German Patent and Trademark Office explained what the public policy objectives for providing the exception related to breeders' use of patented inventions are: Sec. 11, no. 2a of the Patent Act defines the scope of the research exemption for breeding, discovering and developing a new plant variety on the basis of the declaration of the German delegation for the minutes in the Internal Market Council of 27 November 1997 (statement of reasons relating to the draft of an Act to implement the Directive on the legal protection of biotechnological inventions, document of the Bundestag BT-Drucksache 15/1709, p. 15). The provision shall ensure that breeding, discovering and development of new plant varieties is not unreasonably impeded by patent protection for biological material. $^{16}$

In France, in 2004 $4^{17}$ the Article L613-5-3 of the Code de la Propriété Intellectuelle ${ }^{18}$ was adopted that contains exception according to which intellectual property rights

13 WIPO, Standing Committee on the Law of Patents, Exceptions and Limitations to Patent Rights: Farmers' and/or Breeders' Use of Patented Inventions, Twenty-First Session, Geneva, Nov. 3 to 7, 2014.

14 Viola Prifti, The Breeder's Exception to Patent Rights as a New Type of Research Exception, 0(0) Rights \& Science 109 (2017).

15 Patent Act as published on 16 December 1980 (Federal Law Gazette 1981 I p. 1), as last amended by Article 4 of the Act of 8 October 2017 (Federal Law Gazette I p. 3546) (Feb. 28, 2020), available at https://www.gesetze-im-internet.de/englisch_patg/englisch_patg.html.

16 Germany, German Patent and Trademark Office/WIPO, Questionnaire on Exceptions and Limitations to Patent Rights, at 21 (Feb. 28, 2020), available at https://www.wipo.int/export/sites/www/scp/en/ exceptions/submissions/germany.pdf.

17 Loi $n^{\circ}$ 2004-1338 du 8 décembre 2004 relative à la protection des inventions biotechnologiques [Law No. 2004-1338 of 8 December 2004 relating to the protection of biotechnological inventions] (Feb. 28, 2020), available at https://www.legifrance.gouv.fr/affichTexteArticle.do;jsessionid=10397326E3C6F C3FF5D0FE98B278E3E3.tplgfr22s_3?cidTexte=JORFTEXT000000445183\&idArticle=LEGIARTI00000 $6281607 \&$ dateTexte $=20041209$.

18 Le Code de la propriété intellectuelle, créé par la loi n ${ }^{\circ} 92-597$ du $1^{\text {er }}$ juillet 1992 [Intellectual Property Code, created by Law No. 92-597 of 1 July 1992] (Feb. 28, 2020), available at https://www.legifrance.gouv.fr/ affichCode.do?cidTexte=LEGITEXT000006069414\&dateTexte $=20200108$. 
based on patent shall not extend to the acts performed with a view to creating or discovering and developing other plant varieties. ${ }^{19}$

In the Netherlands, the amendment to the Dutch Patent Act regarding a limited breeder's exception entered into force in 2014 in order to create an opportunity to discover and develop new plant varieties. According to the answer received for the WIPO research ${ }^{20}$ before accepting this exception the Dutch Association of plant breeders held a public debate on the necessity of the introduction of a breeder's exemption. They have pointed out that

the pool of plant varieties available for further breeding activities has declined rapidly over the last decade, due to increasing existing patent rights. ${ }^{21}$

This exception set out in Article 53.2.b of the Dutch Patent Act allows the use of patented biological material for breeding purposes - to cultivate, or discover and develop new plant varieties. Furthermore, according to Article $53 \mathrm{c}$ of the Dutch Patent Act for the purposes of agricultural exploitation a farmer may use the products of his harvest for further propagation/multiplication by himself in his own company. ${ }^{22}$ Along with this amendment the Dutch Association of Plant Breeders (Plantum) proposed the introduction of a comprehensive breeding exemption in patent law, according to which breeders can develop new plant varieties and exploit them commercially, making use of patent-protected biological material, which is subject to patent rights, without permission from the patent holders. ${ }^{23}$ This proposal is concerned only with patented products (gene traits) and not with patented processes (breeding techniques) ${ }^{24}$ Nonetheless, the commercial exploitation of new plant varieties in the Netherlands is currently protected by patent law.

According to amended ${ }^{25}$ Article 9 of the Swiss Federal Act on Patents for Inventions the effects of the patent do not extend to the use of biological material for the purpose of the production or the discovery and development of a plant

19 France, National Institute of Industrial Property/WIPO, Questionnaire on Exceptions and Limitations to Patent Rights (Feb. 28, 2020), available at https:/www.wipo.int/export/sites/www/scp/en/exceptions/ translation/france_en.pdf.

20 WIPO, Exceptions and Limitations to Patent Rights, supra note 12.

21 The Netherlands, Netherlands Patent Office/WIPO, Questionnaire on Exceptions and Limitations to Patent Rights, at 24 (Feb. 28, 2020), available at https://www.wipo.int/export/sites/www/scp/en/ exceptions/submissions/netherlands.pdf.

22 Kingdom Act of 15 December 1994, containing rules in respect of patents (the Dutch Patents Act) (Feb. 28, 2020), available at https://wetten.overheid.nl/BWBR0007118/2019-02-01.

23 Trojan, supra note 4.

24 Prifti 2017.

25 Amended by No. I of the FA (22 June 2007), in force since 1 July 2008 (AS 2008 2551; BBI 2006 1). 
variety. ${ }^{26}$ Agreeing with the current Swiss climate of opinion, acts that are undertaken to determine the quality of being achieved or being appropriate for a particular purpose and those for the further technical development of a disclosed invention should be permitted. ${ }^{27}$ At the same time, the provisions of patent law are aimed at the achievements and development of the invention in agriculture. As stated by Article 35a of the Federal Act on Patents for Inventions that regulates farmers' privilege ${ }^{28}$ farmers who have acquired plant reproduction material placed on the market by the proprietor of the patent or with his consent may reproduce, on their own farm, the product from this material cultivated on their own farm. Herewith agreements which limit or revoke the farmers' privilege in the area of food and feed production are null and void. ${ }^{29}$

According to Articles 5, 6 of the Swiss Federal Law on the Protection of Plant Varieties $^{30}$ the breeder's [of the originally plant variety] authorization shall not be required for the purpose of breeding other varieties entailing the use of the protected variety for a wide range of acts, including production of the propagating material of the variety protected or conditioning for the purpose of propagation, selling or other marketing. As it was emphasized on the comment from Switzerland

the breeders' privilege is a significant restriction on the Law on the Protection of Plant Varieties which makes possible not only the breeding and development of new plant varieties but also, at the present time, their commercialization without the permission of the legitimate owner of the original plant variety. ${ }^{31}$

Based on this analysis we could conclude that international regulation provides flexibilities for states to be free to determine the appropriate scope of exceptions to intellectual property rights. A number of countries have ensured in their patent law different types of exceptions in order to increase the competitiveness of the seed industry. Currently, we can see a buzz of activity about the commercialization of the seeds obtained as a result of selection using patented materials.

26 Federal Act on Patents for Inventions (Patents Act, PatA) of 25 June 1954 (Mar. 6, 2020), available at https://www.admin.ch/opc/en/classified-compilation/19540108/201904010000/232.14.pdf.

27 Switzerland, Swiss Federal Institute of Intellectual Property/WIPO, Questionnaire on Exceptions and Limitations to Patent Rights, at 5 (Mar. 6, 2020), available at https://www.wipo.int/export/sites/www/ scp/en/exceptions/translation/suisse_en.pdf.

28 The Federal Council defined the plant species to which the farmer's privilege applies. See Ordinance on the Protection of New Varieties of Plants No. 232.161 of 25 June 2008 (Mar. 6, 2020), available at https:// www.upov.int/export/sites/upov/members/en/npvlaws/switzerland/ch_232_161_2008.pdf.

29 Federal Act on Patents for Inventions of 25 June 1954 (Mar. 6, 2020), available at https://www.admin. ch/opc/en/classified-compilation/19540108/201904010000/232.14.pdf.

30 Federal Law on the Protection of Plant Varieties No. 232.16 of 20 March 1975 (Mar. 6, 2020), available at https://www.wipo.int/edocs/lexdocs/laws/en/ch/ch154en.pdf.

31 WIPO, Exceptions and Limitations to Patent Rights, supra note 12. 


\section{Regulation of the Breeders' Exception in the BRICS Countries: Key Features and Challenges}

\subsection{Economic Policy in the BRICS Countries in the Agricultural Sector}

Compared to the Netherlands, Germany, France, and Switzerland, developing countries are less likely to use exceptions to patent rights despite the urgent need in terms of the public interest. Ensuring food security is an important task for BRICS economies, as these countries are home to almost three billion people. Thus, there is a need to share the existing know-how for the progress and development of all the BRICS countries..$^{32}$ The Food and Agriculture Organization (FAO) noted that the BRICS countries with their emerging economies are well placed for a leadership role in helping eradicate global hunger and poverty by $2030 .{ }^{33}$ Nonetheless, these economies face many challenges, so there is a real need to develop approaches to stimulate innovations in the agricultural sector and to ensure food security.

Despite the fact that from 2004 to 2014 Brazil has been known worldwide for reducing food insecurity by improving food access, supporting the food production by small farmers, and enhancing food security governance, the recent financial and political crisis (2015 to 2017) has strongly affected Brazilians, with a great increase in severe food insecurity. ${ }^{34}$

The Global Hunger Index (GHI) ranks India at the high end of the 'serious' category, as India continues to perform poorly with hunger and malnutrition. Many in India also experience hidden hunger. Latent hunger refers to a situation of chronic micronutrient deficiency, where a person might have access to sufficient calories, but lacks adequate micronutrients. ${ }^{35}$

In China, ensuring national interests is a tough priority. They are aimed at improving the quality and efficiency of agricultural products and market competitiveness, as well as ensuring the efficient supply of important agricultural products, especially grain. An important place in Chinese politics is allotted to establishing a comprehensive food science and technology innovation system: to speed up the breeding of high-

32 Malini L. Tantri \& Kumar Shaurav, Food Security in BRICS - Current Status and Issues, Institute for Social and Economic Change, Working Paper 419 (2018) (Mar. 7, 2020), available at http://www.isec.ac.in/ WP\%20419\%20-\%20Malini\%20L\%20Tantri_12\%20-\%20Final.pdf.

33 BRICS Countries Well Placed for a Leadership Role in Helping Eradicate Global Hunger and Poverty by 2030, Food and Agriculture Organization (FAO), 16 June 2017 (Mar. 7, 2020), available at http:// www.fao.org/news/story/en/item/896519/icode/.

34 Luna R. Machado de Sousa et al., Food Security Status in Times of Financial and Political Crisis in Brazil, 35(7) Cadernos de Saúde Pública [online] (2019) (Mar. 7, 2020), available at http://www.scielo.br/ scielo.php?pid=S0102-311X2019000905008\&script=sci_arttext.

35 Neetu A. George \& Fiona H. McKay, The Public Distribution System and Food Security in India, 16(17) International Journal of Environmental Research and Public Health 3221 (2019) (Mar. 7, 2020), also available at https://advance.lexis.com/api/document?collection=news\&id=urn:contentltem:5XTC3821-JBHT-D04S-00000-00\&context=1516831. 
quality special rice, strong gluten and weak gluten wheat, as well as green and highquality varieties such as high starch, high protein and high oil corn, and transform grain production from high yield to both high yield and high quality. ${ }^{36}$

According to the 2019 Report of World Wide Fund for Nature (WWF), South Africa will have to produce $50 \%$ more food by 2050 to feed an estimated population of 73 million people. ${ }^{37}$ It is a real challenge for the government in the context of food security that needs a more innovative approach in legislation.

In Russia there are two essential tasks for the economy in the agricultural sector. The first is to ensure food security in the country. And here the key barrier is the lack of access to genetic information. Russia has a collection of seeds, formed in the USSR with the help of the outstanding genetic scientist breeder N. Vavilov. However, these collections are entangled in an inefficient administrative system, which does not allow it to be launched into the stream of commerce. ${ }^{38}$ But in this article we consider the other side of food security - the innovative development of the agricultural sector. The second essential task is the need to increase agro-food exports. The national project on international cooperation and export provides for an increase in annual food sales from Russia abroad to $\$ 45$ billion by 2024 - almost double the current one. ${ }^{39}$

In 2012 in order to implement the Federal Law "On the Development of Agriculture" the State Program for the Development of Agriculture and regulation of agricultural markets, raw materials and food for 2013-2020 was adopted. According to this Program, the main objectives are to ensure food independence of Russia and increase the competitiveness of Russian agricultural products in the domestic and foreign markets. ${ }^{40}$ It seems that these tasks will be relevant also after 2020.

36 Food Security in China, China Daily, 15 October 2019 (Mar. 7, 2020), available at https://global. chinadaily.com.cn/a/201910/15/WS5da51557a310cf3e3557076c.html.

37 Tatjana von Bormann, Agri-Food Systems: Facts and Futures: How South Africa Can Produce 50\% More by 2050, WWF South Africa (2019), at 4 (Mar. 7, 2020), available at https://dtnac4dfluyw8.cloudfront. net/downloads/wwf_food_report_facts_and_futures_2019.pdf.

38 Thesis by Alexey Ivanov during a speech at $11^{\text {th }}$ International Conference for agricultural producers and suppliers of agricultural inputs and services "Where the Margin Is 2020" (Mar. 7, 2020), available at http://ikar.ru/wherethemarginis/.

Директор Института права и развития Высшей школы экономики Алексей Иванов о том, как России выйти на цифровой уровень в сельском хозяйстве // Коммерсант. 23 декабря 2019 г. [Director of the HSE-Skolkovo Institute for Law and Development Alexey Ivanov on How Russia Can Enter the Digital Level in Agriculture, Kommersant, 23 December 2019] (Mar. 7, 2020), available at https://www. kommersant.ru/doc/4198602.

40 Государственная программа развития сельского хозяйства и регулирования рынков сельскохозяйственной продукции, сырья и продовольствия на 2013-2020 годы, утв. Постановлением Правительства Российской Федерации от 14 июля 2012 г. № 717 [State Program for the Development of Agriculture and Regulation of Agricultural Markets, Raw Materials and Food for 2013-2020, approved by the Resolution of the Government of the Russian Federation of 14 July 2012 No. 717] (Mar. 7, 2020), available at http://government.ru/rugovclassifier/815/events/. 
Currently, the creation of new generation plant varieties and hybrids resistant to drought, diseases, herbicides, and pests in Russia is underestimated and does not have the proper legislative support. As elsewhere in the world, the topic of GMOs in Russia is the subject of heated public and political discussions. According to the 2013 Decree of the Government of Russia No. 839 the state registration of genetically modified organisms (GMOs) was to begin. ${ }^{41}$ However, under pressure from the public, it was decided to postpone its entry into force until 2018, in view of the need for a deeper assessment of the problem. According to the experts, the key problem in the GMO market in Russia is its absence. The state finances new developments, but does not create opportunities for their commercialization. ${ }^{42}$

Furthermore, a number of studies in the field of the agricultural sector indicate an insignificant contribution of the agricultural sector to become an innovative vehicle of development of the Russian economy ${ }^{43}$ Russian agricultural producers are implementing individual innovation projects, but the prevalence of innovation in the whole agricultural sector remains quite low. It is important to note that, according to Russian Federal State Statistics Service professor Alexander Bogachev, ${ }^{44}$ the following indicators of innovative activity of agricultural organizations in the Russian Federation in 2016-2017 are thus:

\begin{tabular}{|l|c|c|c|c|c|c|}
\hline \multirow{7}{*}{ An indicator } & \multicolumn{2}{|c|}{$\begin{array}{c}\text { The share } \\
\text { of innovative } \\
\text { products in the } \\
\text { total volume of } \\
\text { products shipped }\end{array}$} & \multicolumn{2}{|c|}{$\begin{array}{c}\text { The share } \\
\text { of organizations } \\
\text { implementing } \\
\text { innovations }\end{array}$} & $\begin{array}{c}\text { The share } \\
\text { of organizations } \\
\text { implementing } \\
\text { technological } \\
\text { innovations }\end{array}$ \\
\cline { 2 - 8 } & 2016 & 2017 & 2016 & 2017 & 2016 & 2017 \\
\hline Crop production & 1.1 & 2.0 & 4.2 & 4.2 & 3.7 & 3.9 \\
\hline Farm animals & 1.6 & 1.7 & 4.7 & 3.9 & 3.9 & 2.9 \\
\hline Mixed-farming & 1.2 & - & 2.7 & 1.3 & 1.8 & - \\
\hline
\end{tabular}

41 Постановление Правительства Российской Федерации от 23 сентября 2013 г. № 839 «О государственной регистрации генно-инженерно-модифицированных организмов, а также продукции, полученной с их применением» [Resolution of the Government of the Russian Federation No. 839 of 23 September 2013 No. 839. On State Registration of Genetically Modified Organisms, as Well as Products Obtained with Their Use] (Mar. 7, 2020), available at http://government.ru/docs/6128/.

42 Обзор рынка биотехнологий в России и оценка перспектив его развития // Frost \& Sullivan. 2014 [An Overview of Biotechnology in the Russian Market and the Assessment of the Prospects of its Development, Frost \& Sullivan (2014)] (Mar. 7, 2020), available at https://www.rvc.ru/upload/iblock/ e21/20141020_Russia_Biotechnology_Market_fin.pdf.

43 Богачев А.И. Инновационная деятельность в сельском хозяйстве России: современные тенденции и вызовы // Вестник НГИЭИ. 2019. № 5(96). Р. 95-106 [Alexander I. Bogachev, Innovative Activities in Agriculture of Russia: Modern Trends and Challenges, 5(96) Bulletin of NGIEI 95 (2019)].

44 Alexander Bogachev, Ph.D. (Economy), associate professor, Director of Center for labor protection and agricultural consulting Orel State Agrarian University, Orel (Russia). 


\begin{tabular}{|l|c|c|c|c|c|c|}
\hline $\begin{array}{l}\text { Auxiliary activities } \\
\text { in the production } \\
\text { of agricultural } \\
\text { crops and post- } \\
\text { harvest processing } \\
\text { of agricultural } \\
\text { products }\end{array}$ & 0.7 & 1.8 & 1.8 & 2.4 & 1.5 & 2.1 \\
\hline Total agriculture & 1.4 & 1.8 & & & & \\
\hline Total economics & 8.5 & 7.2 & 8.4 & 8.5 & 7.3 & 7.5 \\
\hline
\end{tabular}

In this case among a number of negative features of the innovative development of Russian agriculture Alexander Bogachev identified the following:

- poor competitiveness of domestic developments in foreign markets;

- orientation of leading agricultural enterprises for the purchase of foreign scientific and technical solutions and technologies;

- a weak mechanism of research and development activities in the absence of incentives for the development of innovations among agricultural producers $\mathrm{s}^{45}$.

At the same time, according to the Agricultural Market Review of the Deloitte Research Center, the Index for assessing the state of the agricultural sector in 2019 decreased by 14 points compared to 2018 , to $0.26{ }^{46}$ The problems of agriculture in Russia in 2019 include insufficient penetration of high technologies. ${ }^{47}$

Innovative development provides an opportunity to improve the technological, technical, organizational and economic base of agricultural production, and the obtaining of competitive products. Among the many problems of the domestic agricultural sector, the task of technological modernization stands out. ${ }^{48}$

To consider a possible solution to the mentioned tasks we turn to the intellectual property regulation in the BRICS countries.

\subsection{The Breeders' Exception in the Legislation of the BRICS Countries}

In Brazil, the Law on Industrial Property contains breeders' use of patented inventions exception. According to Article 43, part V of Law No. 9.279 the noncommercial use of the patented product of a patent related to living material by third parties is allowed as an initial source of variation or propagation to obtain other

45 Bogachev 2019, at 99.

46 From -1 to 1 , where -1 is a negative rating, +1 is a positive rating; where one point is 0.01 .

47 Обзор рынка сельского хозяйства - 2019 // Deloitte. 2019 [Agricultural Market Review in Russia in 2019, Deloitte Research Center (2019)], at 21 (Mar. 7, 2020), available at https://www2.deloitte.com/ ru/ru/pages/consumer-business/articles/snapshot-of-the-russian-agroindustry.html.

48 Федоренко В.Ф. Научно-информационное обеспечение инновационного развития в сфере сельского хозяйства [Vyacheslav F. Fedorenko, Scientific and Informational Support of Innovative Development in the Field of Agriculture] (Moscow: Rosinformagrotekh, 2011) (Mar. 7, 2020), available at https://rucont.ru/efd/213381. 
products. ${ }^{49}$ Such exception was provided because it is fundamental to stimulate the research and development of new plant varieties in order to establish a reasonable balance of interests between rightholders and users of intellectual property rights, as well as to protect public interests. ${ }^{50}$ Also in accordance with Article 43, part VI of specified Law No. 9.279 patent rights do not apply to third parties who, in the case of patents related to living matter, use, place in circulation or commercialize a patented product that has been introduced lawfully onto the market by the patentee or his/her licensee, provided that the patented product is not used for commercial multiplication or propagation of the living matter in question.

In 2019 the Brazilian appeals court's decision reverses a past ruling establishing the rights of small farmers in Brazil. In their initial petition, farmers' unions in 2009 asserted that Monsanto's royalty collection system is arbitrary, illegal and abusive. They argued that it violates their right to freely save seeds for replanting. In April 2012, a civil court sided with farmers, affirming their rights to save seeds and sell their harvests as food or raw material without paying royalties. ${ }^{51}$ According to this court's decision, Monsanto could no longer charge royalties on the commercialization of grains produced with transgenic soybean seeds, tolerant to the herbicide Roundup. It was ordered to Monsanto to return the amounts charged to farmers since the $2003 / 2004$ harvest, adjusted for inflation and plus interest of $1 \%$ per month. The company is also interdicted from prohibiting the donation and exchange of seeds of different crops between soybean growers. The court established that the right to charge for inventions protected by intellectual property rights is based on the Federal Constitution and Article $44^{52}$ of the Industrial Property Law No. 9.279,

49 Law on Industrial Property No. 9.279 of 14 May 1996 (Mar. 6, 2020), available at https://www.wipo.int/ edocs/lexdocs/laws/en/br/br003en.pdf.

50 Brazil, Ministry of External Relations/WIPO, Questionnaire on Exceptions and Limitations to Patent Rights (Mar. 6, 2020), available at https://www.wipo.int/export/sites/www/scp/en/exceptions/ submissions/brazil.pdf.

51 Karine E. Peschard, Monsanto Wins \$7.7bn Lawsuit in Brazil - but Farmers' Fight to Stop its "Amoral" Royalty System Will Continue, The Conversation, 31 October 2019 (Mar. 6, 2020), available at http:// theconversation.com/monsanto-wins-7-7b-lawsuit-in-brazil-but-farmers-fight-to-stop-its-amoralroyalty-system-will-continue-125471.

52 According to Article 44 of the Law No. 9.279 "the patent holder is assured the right to obtain indemnification for improper exploitation of the object of his patent, including that which occurs between the date of publication of the application and the date of granting of the patent. (1) If the transgressor obtained, by any means, knowledge of the content of the filed application prior to the publication, the period of improper exploitation, for purposes of indemnification, shall be calculated beginning with the date of the start of the exploitation. (2) When the object of the patent application refers to biological material, deposited as provided in the Sole Paragraph of Article 24, the right to indemnification shall be recognized only when the biological material has become available to the public. (3) The right to obtain indemnification for improper exploitation, including that related to the period prior to the granting of the patent, is restricted to the content of its object, as provided for in Article 41," (Mar. 6, 2020), available at https://www.wipo.int/edocs/lexdocs/laws/en/br/br003en.pdf. 
and there was never an imposition of this right, but free convenience of farmers applied. $^{53}$

Monsanto got this ruling overturned on appeal. The Brazilian farmers' unions then appealed that decision, leading to the 2019 court's decision ruling against them. According to the decision ${ }^{54}$ farmers cannot save seeds for replanting if the seeds are harvested from Monsanto's patented Roundup Ready soybeans..$^{55}$ Intellectual property on GM soy developed in the laboratory is judged by the Patent Law, and not by the Law on Cultivars. As a result, producers who obtain transgenic soybeans will not be able to use the protection of the cultivar law, ${ }^{56}$ which guarantees the right to reserve the crop product for replanting and marketing as food and raw material, as well as the right of small farmers to donate or exchange reserved seeds. ${ }^{57}$

It should be noted, several innovations have been adopted to the Brazilian agriculture during the last decades. Among these technological advances, the genetically modified organisms (GMOs) have made a significant contribution to increasing the productivity of agricultural practices. Brazil's respective position in the field of GMO cultivation contrasts with the country's technological dependence. Some few foreign companies have patented critical plant biotechnologies, demanding royalties for their usage. ${ }^{58}$

Compared to Brazil according to Indian law there is an exception to new plant variety intellectual rights, but not to patent rights. Thus, a farmer who has bred or developed a new variety shall be entitled for registration and other protection in like manner as a breeder of a variety under the Protection of Plant Varieties and Farmers' Rights Act, 2001. ${ }^{59}$ Wherein nothing contained in this Act shall prevent the use of

53 Decision of the 15a Vara Civel in the case No. 001/1.09.0106915-2 of 4 April 2012 (Mar. 6, 2020), available at http://www3.tjrs.jus.br/site_php/consulta/download/exibe_doc1g_oracle.php?id_comarca=porto_ alegre\&ano_criacao=2012\&cod_documento=1166975\&tem_campo_tipo_doc=S.

54 Decision of the Superior Court of Justice of 9 October 2019 (Mar. 6, 2020), available at https://ww2. stj.jus.br/websecstj/cgi/revista/REJ.cgi/lTA?seq=1838988\&tipo=0\&nreg=201601710999\&SeqCgrma Sessao $=\&$ CodOrgaoJgdr $=\& d t=20191014 \&$ formato=PDF\&salvar $=$ false.

55 Peschard, supra note 51.

56 Plant Variety Protection Law No. 9.456 (1997) (Mar. 6, 2020), available at https://wipolex.wipo.int/ru/text/ 125403.

57 STJ decide que soja transgênica deve ser julgada como patente e não cultivar [Superior Court of Justice Decides That Transgenic Soybeans Should Be Judged as Patents and Not as Cultivates], Canalrural (2019) (Mar. 6, 2020), available at https://www.canalrural.com.br/noticias/agricultura/soja/stj-reconhece-quesoja-transgenica-deve-ser-julgada-como-patente-e-nao-cultivar/.

58 Vinícius Eduardo Ferrari \& Marina Natsumi Pacheco, Propriedade intelectual e inovações tecnológicas na indústria de sementes: discussões sobre os conflitos judiciais entre a Monsanto e os agricultores brasileiros [Intellectual Property and Technological Innovations in the Seed Industry:Discussions About Legal Conflicts Between Monsanto and Brazilian Farmers], 21(43) Revista de estudios sociais [Journal of Social Studies] 89 (2019) (Mar. 6, 2020), available at http://periodicoscientificos.ufmt.br/ojs/index.php/res/article/view/9024/html.

59 The Protection of Plant Varieties and Farmers'Rights Act of 2001 (Mar. 6, 2020), available at http://www. inttladvocare.com/bar_act/The_Protection_of_Plant_Varieties_and_Farmers_Rights_Act_2001.pdf. 
a variety by any person as an initial source of variety for the purpose of creating other varieties. But if the repeated use of such variety as a parental line is necessary for commercial production of such other newly developed variety the authorization of the breeder of a registered variety is required..$^{60}$ According to Article 43 of the Protection of Plant Varieties and Farmers' Rights Act such authorization shall not be given by the breeder of such farmers' variety except with the consent of the farmers or group of farmers or community of farmers who have made contribution to the preservation or development of such variety.

We should also note that India follows the sui generis system as far as plant breeder rights are concerned. ${ }^{61}$ On the basis on Article 39(1)(iv) of the Protection of Plant Variety and Farmers' Right Act a farmer has rights to save, use, sow, resow, exchange, share, or sell his farm produce including seed of a variety protected under this Act. There is one exception: the farmer shall not be entitled to sell branded seed ${ }^{62}$ of a variety protected under this Act.

Currently, Indian farmers are faced with a serious test of the effectiveness of this regulation provision. PepsiCo India Holdings Pvt. Ltd. has filed a lawsuit on intellectual property violation as a result of using a patented variety of potato by Indian farmers. ${ }^{63}$ This case is an important precedent for farmers as well as the corporate farming industry that could have a far-reaching impact on how other food crops are developed, sown and sold in the country. ${ }^{64}$ PepsiCo India Holdings Pvt. Ltd. is the registered breeder of the potato plant variety "FL 2027" (commercial name FC5). In January 2019, it came to the knowledge of the plaintiff that farmers have started the production of this variety of the potatoes by infringing the right of PepsiCo under the Protection of Plant Variety and Farmers' Right Act. ${ }^{65}$ Farmers' association supporters believe this case is a question of India's seed sovereignty, food sovereignty and country's sovereignty.

60 Art. 30 of the Protection of Plant Varieties and Farmers' Rights Act of 2001.

61 India, Patent Office of India/WIPO, Questionnaire on Exceptions and Limitations to Patent Rights (Mar. 6, 2020), available at https://www.wipo.int/export/sites/www/scp/en/exceptions/submissions/india_2.pdf.

62 "Branded seed" means any seed put in a package or any other container and labelled in a manner indicating that such seed is of a variety protected under this Act.

63 PepsiCo India Holdings Pvt. Ltd. versus Bipin Patel, Commercial Trademark Suit No. 23 of 2019, Commercial Court at City Civil Court, Ahmedabad; PepsiCo India Holdings Pvt. Ltd. versus Vinod Patel, Commercial Trademark Suit No. 24 of 2019, Commercial Court at City Civil Court, Ahmedabad; PepsiCo India Holdings Pvt. Ltd. versus Chabilbhai Patel, Commercial Trademark Suit No. 25 of 2019, Commercial Court at City Civil Court, Ahmedabad; PepsiCo India Holdings Pvt. Ltd. versus Haribhai Patel, Commercial Trademark Suit No. 26 of 2019, Commercial Court at City Civil Court, Ahmedabad.

64 Priscilla Jebaraj, Now, PepsiCo Offers to Settle Case Against Gujarat Potato Farmers, The Hindu, 26 April 2019 (Mar. 6, 2020), available at https://www.thehindu.com/news/national/pepsico-offers-conditionalsettlement-to-gujarat-potato-farmers/article26953341.ece.

65 PepsiCo India Holdings Pvt. Ltd. versus Bipin Patel, Commercial Trademark Suit No. 23 of 2019, Commercial Court at City Civil Court, Ahmedabad (Mar. 6, 2020), available at https://www.gaonconnection.com/ pdf_upload/pdf_upload-333425.pdf. 
They were lobbying the government to back the accused farmers' side ${ }^{66}$ However, the first court decisions were in favor of the PepsiCo India Holdings Pvt. Ltd., and did not take into account the provisions of Article 39(1)(iv) of the Protection of Plant Variety and Farmers' Right Act. At the same time, the court referred to Articles 64 and 65 of this Act. According to the Article 64(a):

Subject to the provisions of this Act, a right established under this Act is infringed by a person who, not being the breeder of a variety registered under this Act or a registered agent or registered licensee of that variety, sells, exports, imports or produces such variety without the permission of its breeder or within the scope of a registered license or registered agency without permission of the registered licensee or registered agent, as the case may be.

Article 65 states that suit for infringement relating to any registered right in a variety. ${ }^{67}$ However, a final decision on this case has not yet handed down.

In China on the base of Article 25 of the Patent Act a plant variety is not an issue of patent regulation. ${ }^{68}$ But the legislation on the protection of new plant varieties provides breeders' and farmers' exceptions. According to Article 10 of the Regulations of China on the Protection of New Varieties of Plants the exploitation of the protected variety shall not require authorization from, or payment of royalties to, the variety rights holder for breeding and other scientific research activities, or for propagating purposes by farmers on their own holdings, of the propagating material of the protected variety harvested on their own holdings ${ }^{69}$ China's policy is aimed at boosting innovation; therefore, it is not surprising that in the legislation there are restrictions on intellectual property rights aimed at research and development, including the cultivation of new varieties of seeds in the agricultural sector.

In South Africa, according to section 23 of the previous Plant Breeders' Rights Act 1976 a person who procured any propagation material shall not infringe the breeder's rights if he or she: uses or multiplies that propagating material in the development of a different variety; for purposes of bona fide researches; for private or non-commercial purposes; or is a farmer who on his or her holding uses harvested material obtained on such land from that propagating material for purposes of

66 Benjamin Parkin, PepsiCo Offers to Settle with Indian Potato Farmers After Backlash, The Guardian, 26 April 2019 (Mar. 6, 2020), available at https://www.theguardian.com/business/2019/apr/26/pepsico-accusedof-harassment-after-suing-indian-potato-farmers-lays-crisps.

The Protection of Plant Varieties and Farmers' Rights Act of 2001, supra note 59.

68 Patent Law of the People's Republic of China of 1984 (Mar. 6, 2020), available at https://www.wipo. int/edocs/lexdocs/laws/en/cn/cn028en.pdf.

69 Regulations of the People's Republic of China on the Protection of New Varieties of Plants, as amended in 2013 (Mar. 6, 2020), available at https://www.wipo.int/edocs/lexdocs/laws/en/cn/cn391en.pdf. 
propagation. ${ }^{70}$ It seems that these exceptions did not correspond to the full needs of the country in agriculture - the development of innovations and discovery of new plant varieties. This situation does not safeguard either food security or the free farmers' work - traditional subjects of an agricultural sector. To wit, farmers can't exchange seeds or commercialize new plant varieties developed from protected ones.

However, in 2019 the President assented the new Plant Breeders Rights Amendment Act passed in 2018 (hereinafter the Act 2018). This is how the goals are explained in Act 2018 itself:

To provide for a system whereunder plant breeders' rights relating to varieties of certain kinds of plants may be granted; for the requirements that have to be complied with for the grant of such rights; for the scope and protection of such rights; and for the grant of licenses in respect of the exercise of such rights; and to provide for matters connected therewith. ${ }^{71}$

In fact, this means that the intellectual rights of patent holders will be even more strictly protected than before in contrast to the many of countries where intellectual property is not recognized as sacred and inviolable, as an institution of property itself.

On the base of section 10(1)(c) of the Act 2018 a plant breeder's right shall not extend to any act done in respect of that variety for the purposes of breeding other varieties and, except where section 7(3) applies, any act contemplated in section 7(1) and section 7(2) in respect of such other varieties. These provisions list the following actions: the production or reproduction (multiplication); the conditioning for the purposes of propagation; the sale or any other form of marketing; the exporting; the importing; or the stocking for any of the purposes referred to these acts. But according to section 7(3) of the Act 2018 obtaining a license is necessary where a variety is essentially derived from the protected variety, where the protected variety is not itself an essentially derived variety or if the variety is not clearly distinguishable from the protected variety in accordance or whose production requires the repeated use of the protected variety. It seems that these conditions of breeder's exception are very broad and largely negate the exception provided because it is very common when a new variety is essentially derived from the protected variety. Also, based on section 10(1) a plant breeder's right shall not extend to any act if $a$ farmer uses the protected variety. By section 10(2) of the Act 2018, the Minister prescribes the

70 The Act is no longer valid, but it is important to mention it for comparison. Plant Breeders' Rights Act 1976 (Act No. 15 of 1976, as last amended by Plant Breeders' Rights Amendment Act 1996) (Mar. 6 , 2020), available at https://www.wipo.int/edocs/lexdocs/laws/en/za/za068en.pdf.

71 Plant Breeders' Rights Act No. 12 of 2018 (Mar. 6, 2020), available at http://pmg-assets.s3-website-euwest-1.amazonaws.com/4234729-3-2019plantbreedersact12of2018.pdf. 
category or categories of farmers who may use the protected variety; the category or categories of plants that may be used; the uses to which the protected variety may be put; and - where applicable - conditions for payment of royalties; and labelling requirements. ${ }^{72}$ Thus, the using of patented seeds by farmers are tightly controlled by the state, and, in some cases, are accompanied by the payment of royalties.

It appears that the attempt to provide breeders' and farmers' exceptions in new patent law in South Africa was not as successful as it was expected for the country's innovation development and food security. The legislation contains restrictions on these exceptions, particularly conditions for payment of royalties which do not meet the substance and purpose of breeders' and farmers' exceptions.

In comparison with the previous Plant Breeders' Rights Act 1976, the definition "propagating material" was replaced in current legislation by "protected variety." Propagating material is a wider definition and includes any reproductive or vegetative material of a plant that can be used for the propagation of such plant whilst maintaining the essential characteristics of the original plant. ${ }^{73}$

The Companies and Intellectual Property Commission of South Africa refers to the legislative history of passing the bill in 2018 according to which these exceptions were abused to such an extent that investment in the breeding of certain crops was significantly reduced. It was indicated that plant genetic diversity was undermined rather than expanded by granting breeders rights. This has had implications for intellectual property rights and the sustainable use of biodiversity. On the issue of traditional rights related to plant genetic resources for food and agriculture, the new Act proposed these should not be commercialized for personal gain. ${ }^{74}$ But it seems that the mentioned situation did not arise because of the exceptions granted, but because they were not granted in full, not so widely and within actual needs. The provisions of the previous Act provided insufficient incentives for farmers to improve the country's agricultural sector, and in the current legislation they have been further tightened. Moreover, it is the new approaches to regulation, including intellectual property, that ensure the creation of innovative inventions in the agricultural sector and food security.

Progress in the agricultural sector is based on the use and improvement of existing genetic materials. ${ }^{75}$ One of the legislative possibilities for stimulating the creation of technologically advanced seeds is incorporation into the Russian legal system the breeders' exception in the correct manner, which is aimed at creating

72 Plant Breeders' Rights Act No. 12 of 2018, supra note 71.

73 Republic of South Africa, Companies and Intellectual Property Commission of South Africa/WIPO, Questionnaire on Exceptions and Limitations to Patent Rights (Mar. 6, 2020), available at https://www. wipo.int/export/sites/www/scp/en/exceptions/submissions/safrica_rev.pdf.

74 Id.

75 Correa, supra note 1. 
innovative solutions in agriculture, ensuring food security and the competitiveness of the agricultural market. The Russian Civil Code does not grant a legal protection to an invention for plant varieties and biological methods for their preparation, i.e. methods consisting entirely of crosses and selection, with the exception of microbiological methods and products obtained by such methods. ${ }^{76}$ However, for a new plant variety that meets the eligibility criteria and those related to botanical species, the list of which is established by the federal executive body, a patent is issued (Article 1413 of the Civil Code). Thus, a new plant variety in Russia is defended as a breeding achievement.

The chapter on breeding achievements contains the breeders' exception, which refers to an unlimited circle of persons. On the base on Article 1422(3) of the Civil Code the use of a protected breeding achievement as a source material for the creation of new plant varieties does not constitute a violation of the exclusive right to a breeding achievement.

But it's a precarious rule. The Civil Code also contains provisions that relate to a patent for an invention. According to Article 1350 of the Civil Code, a technical solution is protected as an invention in any field related to a product (in particular, a device, substance, microorganism strain, plant or animal cell culture) or a method, including the use of a product or method for a specific purpose. And based on the analysis of the provisions of the Civil Code, if the owner of a breeding achievement wants to use a patent for an invention to get a new plant variety, he cannot do this: in Article 1359 of the Civil Code the list of actions that do not violate the exclusive right to an invention does not contain the breeders' exception. Thus, it may be possible also to patent the innovative plant varieties or biotechnology genes that are an industrially applicable solution, ${ }^{77}$ and prohibit breeders from using seeds of this invention. It could be a possible situation that one person has a patent for an invention, and another has a patent for a new plant variety on the same object. Prevention of such situations affecting food security is an important task for the legislator.

76 Гражданский кодекс Российской Федерации от 18 декабря 2006 г. № 230-Ф3 [Civil Code of the Russian Federation of 18 December 2006 No. 230-FZ], subcl. 1 of cl. 6 of Art. 1350 (Mar. 6, 2020), available at http://www.consultant.ru/document/cons_doc_LAW_64629/.

77 Patent for invention No. 2252960 / Gene, determining the resistance of plants to diseases, and its use. Patent for invention No. 2522828 / Biological DNA marker for identification of the potato virus resistance gene $x$.

Patent for invention No. 2483109 / Triticum kiharae wheat genes encoding antimicrobial peptides.

Patent for invention No. 2457251 / Stellaria media star genes encoding protective peptides.

Patent for invention No. 2361920 / Gene conferring resistance to phytophthora infestans (late blight) in the family solanaceae.

Patent for invention No. 2518241 / A barley with a low content of hordeins. Presents a barley plant that produces grain and is homozygous in at least two loci for introduced genetic variations.

Patent for invention No. 2525933 / New mutation involved in increased tolerance of plants to imidazolinone herbicides. 
In order to ensure access to seeds in developing countries, it is not worth patenting seeds. However, in Russia, the issue of patenting seeds is open, not only with regard to selection methods. ${ }^{78}$ In some cases, with the development of technology and the creation of the possibility of turnover in the Russian market of genetically modified seeds it may be possible without clear regulation patenting innovations because it could be a solution to a specific problem in the agricultural sector. With the development of technologies in the breeding industry in the world and the possible future appearance of genetically modified seeds in the Russian market, legal uncertainty may arise if it is necessary to regulate the selection of innovative and technologically advanced seeds of new plant varieties.

Progress in the agricultural sector is based on the use and improvement of existing genetic materials. ${ }^{79}$ One of the legislative possibilities for stimulating the creation of technologically advanced seeds is providing the breeders exception also in the section of the Civil Code which deals with invention patents. The relevant provisions should clarify that the use of a patented invention for creating or developing a new plant variety is not a violation of the exclusive rights of the patent holder.

On the basis of the above the correct regulation of intellectual property rights exceptions should be aimed at ensuring food security and increasing the competitiveness of the BRICS countries. The need for exceptions to intellectual property rights is due, among other things, to technological development goals (China here is a prominent example). Intellectual property regulation is also important to prevent the capture of the agribusiness sector by international companies ruining farmers as participants in traditional farming (as we can see in India). In Brazil, ${ }^{80}$ India, ${ }^{81}$ China, ${ }^{82}$ and Russia, the farmer's right and/or breeder's right do not fall within the patent law. According to patent law in these states all or part of living beings (all forms of plants and animals including seeds), except transgenic microorganisms, are

78 Patent for invention No. 2505957 / A method for producing hybrids between cultivated potato solanum tuberosum and 1evn diploid wild potato species. The invention relates to the breeding of potato plants Solanum tuberosum.

Patent for invention No. 2479990 / A method of soybean hybridization. The invention relates to breeding soybean plants.

Patent for invention No. 2458132 / Regulating the height of plants gene and its application. The invention relates to the field of biotechnology and can be used in agriculture. A method for producing a plant is proposed, which involves introducing a gene from Arabidopsis thaliana, which encodes a polypeptide having the function of inhibiting plant growth. The introduction of this gene can be used not only to regulate the height of plants, but also to increase tillering and/or crop yields.

Correa, supra note 1. wipo.int/edocs/lexdocs/laws/en/br/br003en.pdf.

81 Patents Act of 1970, Art. 3(j) (Mar. 6, 2020), available at http://www.ipindia.nic.in/writereaddata/Portal/ IPOAct/1_113_1_The_Patents_Act_1970_-_Updated_till_23_June_2017.pdf.

82 Patent Law of the People's Republic of China of 1984, Art. 25 (Mar. 6, 2020), available at https://www. wipo.int/edocs/lexdocs/laws/en/cn/cn028en.pdf. 
not patentable. In Brazil and China, the use and exchange by farmers of farm-saved seeds is legal, since those acts are outside the scope of the breeder's rights. ${ }^{83}$ It stands to reason the regulation in each country is determined by its specifics. Nevertheless, we believe that the BRICS countries should draw on the experience of Brazil, where the agri-industrial sector is developing technologically due to the firm position of the state regarding GMOs and the breeders' exception spreads on patented inventions in order to stimulate the research and development of new plant varieties.

\section{The Core Question About the Breeders' Exception}

The situation where one object can be patented as an invention and as a new plant variety by different persons, is not a specific issue only for Russia. It is a core question which should be resolved by the breeders' exception.

In fact, the problem of the intersection between breeders and patent holder rights could be solved in different ways (for example, by compulsory licensing). It seems the specific breeders' exception is a more effective and practical way of dealing with the problem.

In a number of countries, compulsory licenses are issued to breeders to use their patented inventions. The issuance of compulsory licenses confirms the fact that breeders need to use patented objects to obtain new plant varieties. According to the responses from countries received by the WIPO Standing Committee on the Law of Patents during the preparation of the "Exceptions and Limitations to Patent Rights: Farmers' and/or Breeders' Use of Patented Inventions" research:

Some Member State ${ }^{84}$ reported that their compulsory license and compulsory cross-license procedures applied to plant breeders' use of a patented invention, and patent holder's use of a plant protected by a plant variety right. ${ }^{85}$

The decisions of the Enlarged Board of Appeal of the European Patent Office's $(E B O A)$ concerning the patenting of essentially biological processes for the production of plants and animals are a good example of resolving the issue in a different way. In its decisions $\mathrm{G} 0002 / 07^{86}$ and $\mathrm{G} 0001 / 08^{87} \mathrm{EBoA}$ set up the rule that

83 Carlos M. Correa, Implementing Farmers' Rights Relating to Seeds, South Centre, Research Paper 75 (March 2017) (Mar. 6, 2020), available at https://www.southcentre.int/wp-content/uploads/2017/05/ RP75_Implementing-Farmers-Rights-Relating-to-Seeds_EN-1.pdf.

84 Bulgaria, France, Lithuania, Moldova, Poland, the Republic of Serbia.

85 WIPO, Exceptions and Limitations to Patent Rights, supra note 12.

86 G 0002/07 (Broccoli/PLANT BIOSCIENCE) of 9 December 2010 (Mar. 7, 2020), available at https://www. epo.org/law-practice/case-law-appeals/recent/g070002ep1.html.

87 G 0001/08 (Tomatoes/STATE OF ISRAEL) of 9 December 2010 (Mar. 7, 2020), available at https://www. epo.org/law-practice/case-law-appeals/recent/g080001ex1.html. 
methods for the traditional breeding of plants do not amount to a technical process and therefore are unpatentable; claims directed to any nonmicrobiological processes for the sexual crossing of the whole genome of plants are considered as being "essentially biological"; the existence of an additional step of a technical nature which serves to enable or assist the performance of the steps of sexually crossing the plants or subsequently selecting the offspring, does not avoid the exclusion from patentability. In contrast, if at least one technical step is performed in addition to the steps of sexually crossing and selection, then the process could be patentable. ${ }^{88}$

EU Directive 98/44/EC lays down that an invention concerning plants is patentable, if the technical feasibility of this invention is not confined to a particular plant variety. Also plant varieties and essentially biological processes for the production of plants should be excluded from patentability. Processes are "essentially biological" if they consist entirely of natural phenomena such as crossing or selection..$^{90}$

It seems that the goal of plant variety protection systems is to grant breeders control over the propagating material of protected varieties and plant breeders' rights could not cover technical processes for the production of those varieties. In contrast, patent protection is available for both products and processes, including innovative solutions in the field of agriculture. Some countries understand that their plant variety protection and patent systems overlap, and therefore allow breeders to obtain plant variety protection and patent protection on the same particular plant..1 But how about a situation where the same plant variety can be patented as an invention and as a new plan variety by different holders? Despite the fact that methods for regulating overlap cases have been developed at the international and national levels, in practice there may be cases when, for various indicators for the same plant variety, a patent and a certificate of ownership of the new plant variety are issued to different persons or organizations. The essential issue is to guarantee plant breeders easy access to biological starting material in the spirit of the innovation model. ${ }^{92}$

88 Committee on Development and Intellectual Property (CDIP), Patent-Related Flexibilities in the Multilateral Legal Framework and their Legislative Implementation at the National and Regional Levels - Part III, CDIP/13/10, 27 March 2014 (Mar. 7, 2020), available at https://www.wipo.int/meetings/ en/doc_details.jsp?doc_id=270806.

89 Directive 98/44/EC of the European Parliament and of the Council of 6 July 1998 on the legal protection of biotechnological inventions (Mar. 7, 2020), available at https://eur-lex.europa.eu/legal-content/ EN/TXT/?uri=CELEX\%3A31998L0044.

Trojan, supra note 4.

91 The Differences Between Plant Variety Protection and Patent Protection on Plants, Public Citizen's Global Access to Medicines Program (Mar. 7, 2020), available at https://www.citizen.org/wp-content/ uploads/differences-between-plant-variety-protection-and-patents-on-plants.pdf.

92 Id. 
According to Article L613-15-1 of the French Intellectual Property Code when a breeder cannot obtain or exploit a plant variety right without infringing on an earlier patent, he or she may request the grant of a license for this patent to the extent that this license is required for working the plant variety to be protected and insofar as the variety constitutes, in relation to the invention claimed in this patent, significant technical progress is at stake and is of considerable economic interest. ${ }^{93}$ Further, if such a compulsory license is granted, the patent holder will be entitled to obtain the grant of a reciprocal license for using the protected variety. ${ }^{94}$ According to the National Institute of Industrial Property (INPI) Article L613-15-1 introduces a compulsory license procedure as an exception to the patent monopoly, with a view to encouraging patent owners to grant a license voluntarily. ${ }^{95}$ At the same time, it is important to note that the French Intellectual Property Code contains breeders' exception in the title devoted to patents for invention. Article L613-5-3 of the French Intellectual Property Code, mentioned above when considering experience from around the world, implies an exception for breeders specifically from the rights of the patent holder to the invention. This regulatory approach is key to the breeders' exception: it makes the situation clear and allows breeders to develop and create new plant varieties using the patented invention.

Based on the consideration, the breeders' exception is necessary not only for a new plant variety, but also for the use of the patented invention in the frame of creating, discovering and developing a new plant variety. On the other hand, breeders should not be able to acquire protection too easily for minor modifications to existing varieties obtained, possibly through cosmetic breeding or genetic engineering, or as free passage without doing serious breeding of their own, problems that the increased application of biotechnology in this field appeared likely to exacerbate. ${ }^{96}$ It is necessary to maintain a balance, but accurately ensure access to materials for breeders for the innovative development of the seed industry.

\section{Conclusion}

To sum up, patent protection without exceptions leads to power and control over food and all its distribution processes. The increasingly concentrated market power enables the ability of big technology-developed companies to affect prices,

93 Intellectual Property Code, supra note 18.

94 WIPO, Exceptions and Limitations to Patent Rights, supra note 12.

95 National Institute of Industrial Property/WIPO, Questionnaire on Exceptions and Limitations to Patent Rights, supra note 19.

96 The Future Control of Food: A Guide to International Negotiations and Rules on Intellectual Property, Biodiversity and Food Security 38 (G. Tansey \& T. Rajotte (eds.), Earthscan: IDRC, 2008). 
reduce competition and set standards within the agriculture sector. ${ }^{97}$ Based on public interest, intellectual property protection should not be unconditional: exceptions are necessary. Some of them were considered in this article.

Breeders' exception aimed at research and development of new plant varieties should provide an opportunity to commercialize new breeding achievements resulting from research. This exception is especially relevant in the modern world, where the gap between the poorest and most prosperous countries is huge, when the world faces the challenge of ensuring food security for all. Breeders' exception provided in the legislation of different countries of the world can create national seed collections to avoid the dependence on foreign companies. Also there is a goal to boost the innovative development and activities that facilitate the application of inventions in production, technological progress and the dissemination of innovative scientific knowledge regarding new plant varieties. And this task of innovative development is more valuable than the unconditional protection of intellectual rights because of the matter at stake. It affects the quality of many people's living in different countries. This approach is recognized both in many developing states and internationally. The creation of innovative breeding achievements that are resistant to various modern challenges is beneficial not only for the breeder, but meets the public interest: providing the population with high-quality products in sufficient amounts.

This value and direction for stimulating innovation is much wider than the field of patent law, and the emphasis on the essence of breeders' exception does not quite coincide with the need of patenting. The right of breeders, according to the legislation of many countries of the world, lies in both using protected varieties as an initial source of variation for the creation of new varieties and commercializing the resulting varieties without authorization from the original breeder. There is an essential difference with patent law, which normally has a very narrow research exemption. ${ }^{98}$ If a new plant variety can be patented for certain technological parameters or the issue of patenting is not clearly resolved in the legislation, there is a need to set up the breeders' exception also with respect to patented inventions. Lack of access to genetic information and materials, and the inability to commercialize received seeds are essential barriers for breeding new varieties. This situation leads to dependence on obtaining hybrid varieties from foreign companies, which poses a threat to food security.

Concerning the farmers' exception, it is worth emphasizing that it is also an important food security institution. In most developing countries, a large share of the population is dependent on agriculture for employment and income. Many of them are small farmers for whom the saving and across-the-fence and inter-community exchanging of seeds are common practices. This is especially the case in countries

\footnotetext{
97 The Future Control of Food, supra note 96 , at 8.

${ }_{98}$ Id. at 37.
} 
and regions where neither the public nor private sectors play a significant role in breeding, production or distribution of seeds..$^{99}$ In developing countries, the position and scope of farmers' rights, based on legislation and, especially, on judicial cases, shows a side of independence on international corporations in the agricultural sector. Some cases against international corporations sometimes show whose interests the government currently supports and what consequences may arise.

It seems clear that international regulation suggests different approaches to the issue of granting exceptions to patent rights. The best practices in a number of European countries are aimed at creating innovative solutions in agriculture, ensuring food security and the competitiveness of the agricultural market. In the BRICS countries these problems of core importance are more acute, but regulation is weaker. Despite some differences in intellectual property regulation approaches, in the BRICS countries legal conditions should be established to create and maintain national strong seed industries in order to ensure the public interest, using flexible approaches and best practices already existing in the world. These legal conditions include the breeders' and farmers' exceptions to patent rights.

\section{References}

George N.A. \& McKay F.H. The Public Distribution System and Food Security in India, 16(17) International Journal of Environmental Research and Public Health 3221 (2019). https://doi.org/10.3390/ijerph16173221

Jaffe A.B. \& Lerner J. Innovation and its Discontents, 1(3) Capitalism and Society 27 (2006). https://doi.org/10.2202/1932-0213.1006

Prifti V. The Breeder's Exception to Patent Rights as a New Type of Research Exception, 0(0) Rights \& Science 109 (2017).

Sousa L. et al. Food Security Status in Times of Financial and Political Crisis in Brazil, 35(7) Cadernos de Saúde Pública [online] (2019).

\section{Information about the author}

Olga Gavrilova (Moscow, Russia) - Research Assistant, HSE-Skolkovo Institute for Law and Development, National Research University Higher School of Economics (11 Pokrovsky Bulvar, Moscow, 167005, Russia; e-mail: oagavrilova@hse.ru).

99 The Future Control of Food, supra note 96, at 38. 